\title{
Influence of Salt Stress on Quality of some Onion (Allium cepa L.) Local Landraces
}

\author{
Carmen BEINŞAN ${ }^{1 *}$, Radu SUMALAN ${ }^{1}$, Sorin VÂTCĂ ${ }^{2}$ \\ ${ }^{1}$ Faculty of Horticulture and Forestry, Banat University of Agricultural Sciences and Veterinary \\ Medicine Timisoara \\ Calea Aradului, 119, 300645, Timisoara, Romania \\ ${ }^{2}$ Faculty of Agriculture, University of Agricultural Sciences and Veterinary Medicine Cluj - Napoca \\ Calea Mănăştur 3-5, 400372, Cluj-Napoca , Romania \\ *Corresponding author: hortic2002@yahoo.com \\ Bulletin USAMV series Agriculture 72(2)/2015 \\ Print ISSN 1843-5246; Electronic ISSN 1843-5386 \\ DOI 10.15835/buasvmcn-agr: 11723
}

\begin{abstract}
Salinity is considered a significant factor affecting crop production and agricultural sustainability in arid and semi-arid region of the world, reducing the value and productivity of the affected land. From this reason the improvement of salt tolerance of cultivated species is a necessity by capitalization of the salt tolerance variability in local landraces of the same species or other species or by the "novo" creation of some varieties by different methods.
\end{abstract}

Keywords: Allium cepa, chlorophyll, proline, salinity, stress

\section{INTRODUCTION}

In recent decades have been made numerous progresses in understanding the biochemical and physiological mechanisms of metabolic adaptation to salt stress at the cellular level (Winicov, 1998). Salinity is one of the most important abiotic stress factors limiting plant growth and productivity. Salinity affects almost every aspect of the physiology and biochemistry of plants and significantly reduces yield (Khan et al., 2008).

Osmotic effects are due to salt-induced decrease in the soil water potential. Salinity results in a reduction of $\mathrm{K}^{+}$and $\mathrm{Ca}^{2+}$ content and an increased level of $\mathrm{Na}^{+}, \mathrm{Cl}^{-}$and $\mathrm{SO}_{4}{ }^{2-}$, which forms its ionic effects (Mansour et al., 2005). Reduction in biomass, photosynthetic capacity changes in leaf water potential and leaf turgor have been reported to have a cumulative effect attributed to salinity stress (Munnas 2002). It is also clear that several soil and other environmental factors do influence plant growth under salinity conditions.

\section{AIMS}

The identification of tolerant genotypes that may sustain a reasonable yield on salt affected soils has been a strategy adopted by scientists to overcome salinity. Experiments aimed to study the main quality indices and to identify the salinity tolerant genotypes from a collection of local landraces of yellow onions and shallots from Timis county.

\section{MATERIALS AND METHODS}

The biological material was represented by 13 local landraces of onion, of which 6 were yellow onions and 7 were onion shallots, collected from areas of Timis County affected by salinity. Name of local populations represent the town and house number where they come from. Local populations of yellow onions: Toager 80, Toager 81, Uivar 305, Foeni 343, Periam 48 and Cruceni 111. Local populations of hasme: Toager 44, Rudna 124, Uivar 305, Uivar 306, Serbian Sânmartinu 180 
, Foeni 343 and Dolat 126. Local populations of onion collected are characterized by many age cultivation in the same household, tolerance to environmental factors, growth and development in terms of biological technology (without chemical fertilizers, just manure, they not use herbicides, not use irrigation only in extreme dry conditions, preservation techniques are ancestral and not sell the yields. The selection of these populations is conducted every year by choosing the most beautiful and useful seed material (seeds, bulbs). The bulbs were evaluated for biometric point of view, aiming at: height, diameter, weight and shape index (ratio of height and diameter), the time of collection. The experimental variants are were: $\mathrm{V}_{0}$ - control (distillated water), $\mathrm{V}_{1}-100$ $\mathrm{mM} \mathrm{NaCl} \mathrm{V}_{2}-200 \mathrm{mM} \mathrm{NaCl}, \mathrm{V}_{3}-300 \mathrm{mM} \mathrm{NaCl}$. For the assessment of salinity tolerance we used solution of 100,200 and $300 \mathrm{mM} \mathrm{NaCl}$, which was applied gradually after each week. The following tests were performed: total chlorophyll content (SPAD units); the accumulation of proline in plants grown in saline conditions $(\mathrm{mg} / \mathrm{ml})$; catalase activity (units/mg protein). The total chlorophyll content (SPAD) of leaves was determined using SPAD-502 portable chlorophyll-meter. The apparatus determines the relative content of chlorophyll, by measuring the absorbance of a leaf in two wavelength ranges. The accumulation of proline is based on the fact that this reacts with ninhydrin and ninhydrin acid and form a yellowreddish color compound, which can be extracted in toluene, and the amount of proline can be assessed by spectrophotometric determination of absorbance compound.

\section{RESULTS}

Height yellow bulb onions showed a value between 3.66 and $5.20 \mathrm{~cm}$, the highest height was recorded at Toager 81 . Regarding the bulbs diameter, 343 Foeni population recorded the highest value of $7.10 \mathrm{~cm}$, while Toager 80 was 5.15 $\mathrm{cm}$. Highest weight presented was Foeni 343 local population with $106.30 \mathrm{~g}$, and the lowest with 53.94 $\mathrm{g}$ was Toager 81 . In the shallot local population case, Toager 44 showed the greatest weight of $127.93 \mathrm{~g}$ having a $4.3 \mathrm{~cm}$ height, respectively $6.1 \mathrm{~cm}$ in diameter. Lowest weight, height and diameter was recorded at Uivar 306 with 39,845 g. The reduction of the chlorophyll content from the leaves under salt-stress conditions due to destruction of the pigments chlorophyll and the instability of protein complex of pigments (Zhang 1991). Also, due to the interference of the salt ions with novo protein synthesis (chlorophyll structural components) rather the decomposition of chlorophyll (Meloni et al., 2003). Therefore it was demonstrated that soil salinity has a negative effect on growth and photosynthetic metabolism.

\section{CONCLUSION}

As for the biometric characteristics in the time of collection, we could notice that at yellow onion, highest weight presented a Foeni 343 local population, and the lowest Toager 81 . In shallot case population great weight were showed the Toager 44. It can be mentioned that a moderate level of stress does not induce a decrease, on the contrary it is an increase of chlorophyll content in some populations. At stressed variants we observed a decrease of chlorophyll content in all local landraces of onion. Local landraces show a great genetic diversity in terms of free proline synthesis making it possible to identify genotypes that have a good tolerance to salinity, such as Foeni 343 and Toager 80 in the case of yellow onions and Rudna 124, Toager 44 and Sânmartinu Sârbesc 180 for shallots. The experiments showed that onions local landraces tested in our experiment are moderately tolerant to salinity and the populations Toager 80, Sânmartinu Sârbesc 180 and Foeni 343 are tolerant to salinity.

\section{REFERENCES}

1. Khan MH, Panda SK (2008). Alterations in root lipid peroxidation and antioxidative responses in two rice cultivars under $\mathrm{NaCl}$-salinity stress. Acta Physyol Plant, 30:91-89.

2. Mansour MM, Salama FZ, Ali M, Hadid AF (2005). Cell and plant responses to $\mathrm{NaCl}$ in Zea Mays L. cultivars differing in salt tolerance. Gen. Appl. Plant Physiol 31(1-2):29-41.

3. Meloni DA, Oliva AA, Martinez ZA, Cambraia J, (2003). Photosynthesis and activity of superoxid dismutase, peroxidase and glutathione reductase in cotton under stress. Environ. Exp. Bot., 49:69-76.

4. Munnas RC (2002). Comparative physiology of salt and water stress. Plant Cell Environ., 25:239-250.

5. Winicov I (1998). New Molecular Approaches to Improving Salt Tolerance in Crop Plants. Annals of Botany 82:703-710.

6. 6. Zhang J, Davies WJ (1991). Antitranspirant activity in xylem sap of maize plants. J. Exp. Bot., 42: 317-321. 